\title{
FACTORS AFFECTING SAFE CLINICAL PRACTICES AS PERCEIVED BY STUDENTS AT TECHNICAL NURSING INSTITUTE IN PORT-SAID
}

\author{
Dr. Samia Mohamed Adam ${ }^{1}$, Dr. Reda Ibrahim El- Mowafy ${ }^{2}$ Naglaa Salah Abed $^{3}$ \\ Prof. of Nursing Administration, Faculty of nursing, Ain shams university ${ }^{1}$,Assist.Prof. \\ of Family and Community Health Nursing, Faculty of nursing, Port Said \\ University ${ }^{2}$,Nursing Specialists at Ezbet el-Borg Hospital in Damietta ${ }^{3}$.
}

\begin{abstract}
Background: Nursing is a practice-based discipline with clinical practice being central to nursing education Therefore; preregistration education mission is to ensure that nursing students can meet quality and safety standards set for patient care. Unsafe students practice is described as a behavior that places the patient or staff in either physical or emotional jeopardy. Aim: to detect factors affecting safe clinical practices as perceived by students at technical nursing institute in Port-Said governorate. A descriptive comparative research design was utilized with a sample 166 students of technical nursing institute, (81 students) of the first and (85 students) of second year. Tool of data collection: A clinical safety practices of nursing students' questionnaire sheet was used. Results: concerning the effective level $(60 \%=1.8)$, First year student have not reach it regarding any factor but second year students reach it regarding two factors which is the educational program and unsafe staff nurse`s practices. There was statistically significant relation between first and second year students regarding unsafe clinical nurse educator`s practices, unsafe nursing students - Clinical nursing educator relationship and The educational program at $(\mathrm{p} \leq 0.05)$. Conclusion: More than half of first year students perceived the most effecting factor is unsafe clinical learning environment. In addition, more than half of second year students the most effecting factor is the educational program. Recommendations: Developing the educational program to pay an equal attention to the clinical practices and the theoretical knowledge.
\end{abstract}

Key words: Clinical Practices, Nursing Students, Safety, Factors. 


\section{INTRODUCTION}

Nursing is a clinical practice discipline. Professional nurses use knowledge and skills without interference from physicians or other disciplines (Kaphagawani et al., 2013). Clinical practice allows students to become socialized into the norms and culture of the nursing profession. This indicates the importance of clinical practice in nursing education (Fitzgerald et al., 2011).

The preregistration education mission is to ensure that nursing students can meet quality and safety standards set for patient care (Willis Commission, 2012). Safety is a fundamental principle of health care and a critical component of quality management (world alliance for patient safety, 2011). Unsafe students practice is described as a behavior that places the patient or staff in either physical or emotional jeopardy. It is an occurrence or pattern of behaviors involving unacceptable risk which may be due to lack of both theoretical and practical teaching (scanlan, 2001.

Therefore, assessment of clinical skills by undergraduate nursing programmers is important to be considered (Rush et al., 2014). Due to their immediate attendance in this process, the students are the best and most reliable sources for detection of clinical problems (Hadizadeh et al., 2005).

Clinical environment is defined as an interactive network of forces within the clinical setting that influences clinical learning by students. Hence, for ensuring the usefulness and effectiveness of clinical environment in learning, these factors must also be specified and reviewed (Chan, Ip 2007).

Staff nurses are clinical registered nurses, who guide, teach and assess nursing students during their clinical practice; therefore, they have an important role to contribute to the achievements of learning outcomes (L€ofmark et al., 2012).

The importance of nursing education is undeniable in personal, professional and clinical skills development (Taghinejad and Mehri, 2008). Through nursing education, nursing students will be able to obtain necessary knowledge and skills to assist public health (Abbaszade et al., 2013).

A clinical educator is a qualified faculty academic or a skilled practitioner, who teaches, supervises and evaluates student nurses in the hospital or simulation 
laboratory (Gillespie and Fetridge, 2009). Clinical Nurse Educator's role is as a knowledge conduit that facilitates the sharing, transfer, and implementation of best practice guidelines; acknowledge the principles of adult learning and also as change agents contributing to the professional growth of practicing registered nurses. Part of Nurse Educator's responsibility, is also to embrace evidence informed practice and translate relevant knowledge into action (Klab 2008 and Gibson, 2011).

On the other hand, The relationship among the nursing students or clinical nurse educator have been considered as the most noteworthy elements for the effectiveness of the clinical learning environment (CLE) with reference to nursing students' learning and professional development. Previous studies (Saarikoski et al., 2013; Sundler et al., 2014 and D'Souza et al., 2015).

Identification and management of an unsafe student remains a challenging and time- consuming process, requiring faculty support and guidance. Although characteristics of unsafe students identified within the literature help to identify potentially problematic situations, clarity of clinical expectations and an understanding of what constitutes unsafe practice is needed. These guidelines would facilitate consistent identification of potential threats to patient safety and student remediation (Scanlan et al., 2001 and Killam et al., 2011).

\section{SIGNIFICANT OF STUDY:}

The quality and safety of health care is a global concern. These considerations are dependent on proficient staff and adequate resources being available within clinical areas and effective educational preparation of nurses (Crotty, 2010). The educational preparation of nurses includes a practice component where learning is integrated in a workplace setting. Clinical practice allows students to become socialized into the norms and culture of the nursing profession (Fitzgerald, et al., 2011).

Identifying problems and challenges with which these students are faced in the clinical learning environment can help stakeholders solve these problems (Joolaee, et al., 2015). Therefore, this study conducted to find out the clinical learning experiences from the nursing student's perspective through detecting the factors affecting safe clinical practices as perceived by technical institute nursing students. 


\section{AIM OF STUDY:}

This study aimed to detect factors affecting safe clinical practices as perceived by students at technical nursing institute in Port- governorate.

\section{Research Question:-}

What are the factors affecting safe clinical practices as perceived by students at technical nursing institute in Port-Said?

\section{SUBJECTS AND METHOD:}

\section{Technical Design:}

A descriptive comparative research design was utilized in this study. This study was conducted at technical nursing institute in Port - Said governorate

\section{Subjects:}

The subject of this study included 166 students, 81student of first year and 85 student second year technical nursing institute. The sample size was determined by using the following equation (Dobson, 2002):

Sample size $(\mathrm{n})=(\mathrm{z} / \Delta)^{2} \mathrm{p} \quad(100-\mathrm{p})$.

\section{Where:}

P: The prevalence of Unsafe clinical practices $=56 \%$ (killam, et al., 2012).

$\mathbf{Z} \boldsymbol{\alpha} / \mathbf{2}$ : a percentile of standard normal distribution determined by confidence level $=1.96$

$\Delta:$ The width of confidence interval $=5 \%$

Sample Size $(n)=158$ student

The calculated sample size is, due to the expected non-participating rate $(5 \%)$; the final sample size was 166.

The number of student from each academic year $(x)$ was determined by using the following equation:

$$
x=\frac{\text { total number of student in academic year } \times \text { total sample size }}{\text { total number of all technical nursing institute students }}
$$

Number of first year student

Number of second year student

$$
=\frac{170 \times 166}{350}=81 \text { student. }
$$

$$
=\frac{180 \times 166}{350}=85 \text { student. }
$$


Tool of data collection: One tool was used to collect data for this study.

\section{Tool: questionnaire Sheet}

The questionnaire sheet was adopted from (Abdul-Aziz, 2014) based on the work of (Laura, 2010) and other related literature (Mascaritolo, 2009 and Kilam, 2010) and consists of the questionnaire sheet to detect factors affecting clinical safety practices as perceived by students at technical nursing institute.

\section{It consisted of two parts:}

\section{Part (1): Personal- Academic characteristics}

This part intended to collect data regarding personal and academic characteristics about technical institute nursing students as age, gender, residence, marital status, source of income per month, level of education completed before entering the nursing program, academic year and the previous practical experiences

\section{Part (2): Clinical safety practices of nursing students' questionnaire}

This part aimed to detect the factors affecting clinical safety practices as perceived by students at technical nursing institute in Port-Said.

It is consists of 64 statements which divided into six dimensions namely:

1- Nursing student`s practices (22 statements). This dimension is divided into two sub dimensions which are student's rules commitment (7 statements) and students' preparation (15 statements).

2- Clinical nursing educators practices (9 statements). 3- The student- educator relationship (6 statements). 4- The clinical educational program (7 statements).

5- The clinical learning environment (11statements). 6- The nurse`s practices (9 statements).

\section{Scoring system:}

Responses were measured on a three point likert- scale ranging from a score of 1 (disagree), 2(somewhat agree) to a score of 3 (agree).The score of the items were summed up and the total was divided by the number of items giving a mean score for this part. Mean score was converted to mean percent. Factor affecting safe clinical practice was considered effective if the score is 60\% (1.8+) (Jecklin, 2000). 


\section{OPERATIONAL DESIGN:}

The operational design of this study includes preparatory phase, tool validity \& reliability, pilot study and field work.

\section{Preparatory Phase:}

It included reviewing of related literature, different studies and theoretical knowledge of various aspects of the problems using books, research articles, internet, periodicals and magazines.

\section{Tool Validity:}

Tool Validity was done by (Abdul-Aziz, 2014).

\section{Tool Reliability:}

Tool Reliability was done by (Abdul-Aziz, 2014). The reliability of tool was ascertained by cronbach`s alpha coefficient with value $(r=0,874)$. It was proved to be strongly reliable.

\section{Pilot Study:}

A pilot study was carried out on $10 \%$ of the study sample (seventeen students) to test the feasibility, applicability of tool, clarity of language and estimate the time required for completing the tool. Subjects involved in pilot study were excluded from the study sample. Pilot study was conducted over a period of two weeks before embarking on the field work of the study. Data obtained from the pilot study was analyzed it helped to find out any obstacles and problems that might interfere with data collection and accordingly there was not modification done. Each interview takes from 15-20 minutes.

\section{Field work:}

Oral consent was taken from the study participants to share in the current study. The study was conducted on 166 student using interview technique that was conducted on an individual basis.

The data had been collected over a period of one month, the actual fieldwork beginning of April 24\} 2 0 1 7 \text { to May 24\2017. Three days per week. From } 1 3 \text { to } 1 4 \text { students were } interviewed every time using previously mentioned study tool each interview take from 
15-20 minutes. Data were then categorized by the researcher, checked and revised.

\section{ADMINISTRATIVE DESIGN:}

Before starting any step in the study, an official letter issued from the Dean of the faculty of nursing to the director of technical nursing institute in Port-Said governorate and requests his cooperation and permission to conduct the study.

\section{Ethical consideration:}

The research approval was obtained from the dean of faculty of nursing Port-Said University. The aim and purpose of the study were explained to director of technical nursing institute as well as the students who were included in the study. Also, it assured maintaining anonymity and confidentiality of the subject data. Students were informed that they were allowed to choose to participate or not in the study and that they had the right to withdraw from the study at any time.

\section{STATISTICAL DESIGN:}

After completion of the data collection, collected data managed, coded, arranged, entered and analyzed according to the type of each data to answer the research questions using SPSS -version 20.0. Data presentation was done using suitable tables and graphs. Statistical analysis of the data $(\mathrm{Kotz}, 2006)$ Data were fed to the computer and analyzed using IBM SPSS software package version 20.0. (Armonk, NY: IBM Corp) (Kirkpatrick LA, Feeney, 2013) Qualitative data were described using number and percent. The Kolmogorov-Smirnov test was used to verify the normality of distribution Quantitative data were described using mean, standard deviation. Significance of the obtained results was judged at the 5\% level. The used tests were: Student t-test For normally distributed quantitative variables, to compare between two studied groups; F-test (ANOVA) For normally distributed quantitative variables, to compare between more than two groups; Chi-square test For categorical variables, to compare between different groups and Fisher's Exact or Monte Carlo correction for chi-square when more than $20 \%$ of the cells have expected count less than 5 .

\section{RESULTS:}

Table (1): clarifies that first year student nurse age ranged between 18 and 22 years, with a mean age $19.23 \pm 0.62 .63 \%$ of them were female. $51.9 \%$ of them were from rural area. 
$98.8 \%$ of them were single in addition $96.3 \%$ of them their financial resource was family income. $86.4 \%$ of them received secondary school education as a previous educational qualification before joining to the institution. $100 \%$ had a previous clinical experience in clinical training; only13.6\% had previous clinical experiences working as a nurse. Their previous clinical experiences period ranged between 2 and 36 month with a mean $6.43 \pm$ 9.20.

In addition, second year student nurse age ranged between 19 and 25 years, with a mean age $20.53 \pm 1.17$. $51.8 \%$ were female. $52.9 \%$ were from rural area. $94.1 \%$ were single. $94.1 \%$ their financial resource was family income. $98.8 \%$ received secondary school education as a previous educational qualification before joining to the institution. $100 \%$ had a previous clinical experience in clinical training; only $22.4 \%$ had previous clinical experiences working as a nurse. Their previous clinical experiences period ranged between 9 and 36 month with a mean $10.55 \pm 4.33$.

Table (2): describes comparison between first and second academic year nursing students perception level regarding factors affecting safe clinical practices of nursing student's. It appears from this table that there is statistically significant relation between first and second year students regarding unsafe nursing student's practices, rules commitment, student preparation, unsafe nursing students -CNE relationship and The educational program at $(\mathrm{p} \leq 0.05)$.

Table findings revealed that, first year students have not reach the effective level of any factor, Furthermore, second year students reach the effective level of two factors.

Table (3): represents that, Comparison between first and second academic year nursing students regarding factors affecting safe clinical practices of nursing student's. It was shown that, there is statistically significant relation between first and second year students regarding unsafe clinical nurse educator`s practices, unsafe nursing students CNE relationship and The educational program at $(\mathrm{p} \leq 0.05)$. it was shown that, regarding first year students the most effecting factor is unsafe clinical learning environment with mean percent $59.82 \pm 23.46 \%$, while regarding second year students the most effecting factor is the educational program, with mean percent $66.55 \pm$ $29.21 \%$, 
Table (1): Comparison between the first and second academic year nursing students regarding personal-academic characteristics $(n=166)$

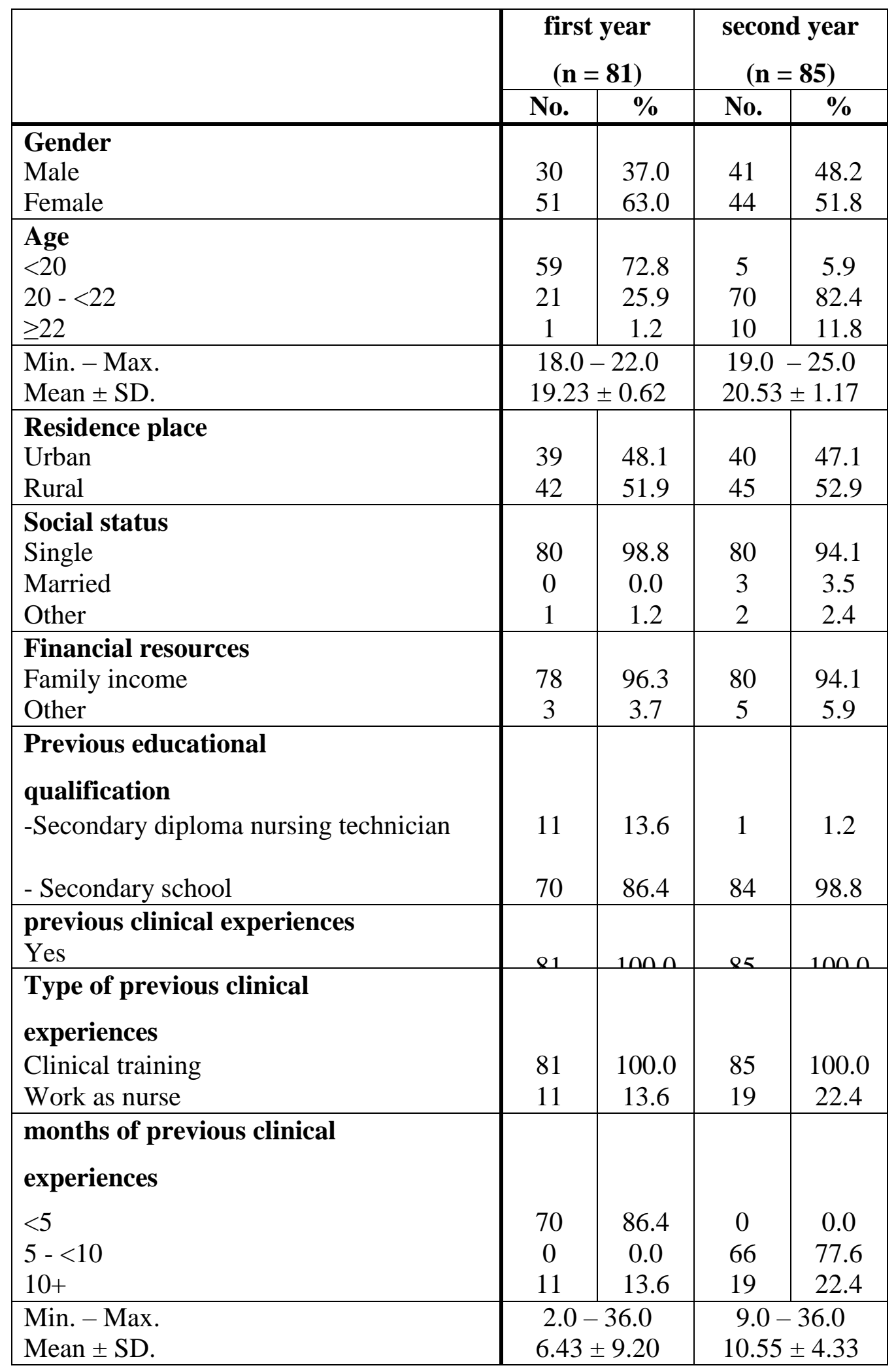


Table (2): Comparison between first and second academic year nursing students perception level regarding factors affecting safe clinical practices of nursing student's

\begin{tabular}{|c|c|c|c|c|c|c|}
\hline \multirow[t]{2}{*}{ Items } & \multicolumn{2}{|c|}{$\begin{array}{l}\text { First year } \\
(\mathbf{n}=\mathbf{8 1})\end{array}$} & \multicolumn{2}{|c|}{$\begin{array}{l}\text { Second year } \\
\qquad(\mathbf{n}=\mathbf{8 5})\end{array}$} & \multirow{2}{*}{$\begin{array}{c}\text { Test of } \\
\text { sig. }\end{array}$} & \multirow[t]{2}{*}{$\mathbf{p}$} \\
\hline & No. & $\%$ & No. & $\%$ & & \\
\hline $\begin{array}{l}\text { Unsafe nursing student's practices } \\
<60 \text { Ineffective } \\
\geq 60 \text { Effective }\end{array}$ & $\begin{array}{l}61 \\
20\end{array}$ & $\begin{array}{l}75.3 \\
24.7\end{array}$ & $\begin{array}{l}46 \\
39\end{array}$ & $\begin{array}{l}54.1 \\
45.9\end{array}$ & $\begin{array}{c}\chi^{2}=8.13 \\
0^{*}\end{array}$ & $0.004^{*}$ \\
\hline $\begin{array}{l}\text { A. Student`s rules commitment } \\
<60 \text { Ineffective } \\
\geq 60 \text { Effective }\end{array}$ & $\begin{array}{l}60 \\
21\end{array}$ & $\begin{array}{l}74.1 \\
25.9\end{array}$ & $\begin{array}{l}49 \\
36\end{array}$ & $\begin{array}{l}57.6 \\
42.4\end{array}$ & $\begin{array}{c}\chi^{2}=4.96 \\
4^{*}\end{array}$ & $0.026^{*}$ \\
\hline $\begin{array}{l}\text { B. Student's preparation } \\
<60 \text { Ineffective } \\
\geq 60 \text { Effective }\end{array}$ & $\begin{array}{l}58 \\
23\end{array}$ & $\begin{array}{l}71.6 \\
28.4\end{array}$ & $\begin{array}{l}46 \\
39\end{array}$ & $\begin{array}{l}54.1 \\
45.9\end{array}$ & $\begin{array}{c}\chi^{2}=5.42 \\
0^{*}\end{array}$ & $0.020^{*}$ \\
\hline $\begin{array}{l}\text { Unsafe clinical nurse educator`s } \\
\text { practices } \\
<60 \text { Ineffective } \\
\geq 60 \text { Effective }\end{array}$ & $\begin{array}{l}51 \\
30\end{array}$ & $\begin{array}{l}63.0 \\
37.0\end{array}$ & $\begin{array}{l}45 \\
40\end{array}$ & $\begin{array}{l}52.9 \\
47.1\end{array}$ & $\begin{array}{c}\chi^{2}=1.70 \\
8\end{array}$ & 0.191 \\
\hline $\begin{array}{l}\text { Unsafe nursing students }- \text { CNE } \\
\text { relationship } \\
<60 \text { Ineffective } \\
\geq 60 \text { Effective }\end{array}$ & $\begin{array}{l}61 \\
20\end{array}$ & $\begin{array}{l}75.3 \\
24.7\end{array}$ & $\begin{array}{l}41 \\
44\end{array}$ & $\begin{array}{l}48.2 \\
51.8\end{array}$ & $\begin{array}{c}\chi^{2}= \\
12.833^{*}\end{array}$ & $<0.001^{*}$ \\
\hline $\begin{array}{l}\text { The educational program } \\
<60 \text { Ineffective } \\
\geq 60 \text { Effective }\end{array}$ & $\begin{array}{l}50 \\
31\end{array}$ & $\begin{array}{l}61.7 \\
38.3\end{array}$ & $\begin{array}{l}28 \\
57\end{array}$ & $\begin{array}{l}32.9 \\
67.1\end{array}$ & $\begin{array}{c}\chi^{2}= \\
13.799^{*}\end{array}$ & $<0.001^{*}$ \\
\hline $\begin{array}{l}\text { Unsafe clinical learning } \\
\text { environment } \\
<60 \text { Ineffective } \\
\geq 60 \text { Effective }\end{array}$ & $\begin{array}{l}39 \\
42\end{array}$ & $\begin{array}{l}48.1 \\
51.9\end{array}$ & $\begin{array}{l}40 \\
45\end{array}$ & $\begin{array}{l}47.1 \\
52.9\end{array}$ & $\begin{array}{c}\chi^{2}=0.02 \\
0\end{array}$ & 0.888 \\
\hline $\begin{array}{l}\text { Unsafe staff nurse`s practices } \\
<60 \text { Ineffective } \\
\geq 60 \text { Effective }\end{array}$ & $\begin{array}{l}38 \\
43\end{array}$ & $\begin{array}{l}46.9 \\
53.1\end{array}$ & $\begin{array}{l}31 \\
54\end{array}$ & $\begin{array}{l}36.5 \\
63.5\end{array}$ & $\begin{array}{c}\chi^{2}=1.86 \\
2\end{array}$ & 0.172 \\
\hline
\end{tabular}

* Statistically significant at $\mathrm{p} \leq 0.05$ 
Table (3): Comparison between first and second academic year nursing students regarding factors affecting safe clinical practices of nursing student's

\begin{tabular}{|c|c|c|c|c|c|c|}
\hline \multirow[b]{2}{*}{ Items } & \multicolumn{2}{|c|}{ First year $(n=81)$} & \multicolumn{2}{|c|}{ Second year $(n=85)$} & \multirow{2}{*}{$\begin{array}{l}\text { Test of } \\
\text { sig. }\end{array}$} & \multirow{2}{*}{$\mathbf{p}$} \\
\hline & Mean \pm SD. & Rank & Mean \pm SD. & Rank & & \\
\hline $\begin{array}{l}\text { (A) unsafe nursing student`s } \\
\text { nractices } \\
\text { Total score } \\
\% \text { score } \\
\end{array}$ & $\begin{array}{c}41.0 \pm 9.50 \\
43.18 \pm 21.58\end{array}$ & 6 & $\begin{array}{l}44.33 \pm 13.92 \\
50.75 \pm 31.63\end{array}$ & 7 & $\begin{array}{l}\mathrm{t}=1.80 \\
\mathrm{e}\end{array}$ & 0.073 \\
\hline $\begin{array}{l}\text { a. student`s rules commitment } \\
\text { Total score } \\
\% \text { score }\end{array}$ & $\begin{array}{c}12.79 \pm 3.44 \\
41.36 \pm 24.61\end{array}$ & 8 & $\begin{array}{c}13.84 \pm 5.01 \\
48.82 \pm 35.76\end{array}$ & 8 & $t=1.57$ & 0.118 \\
\hline $\begin{array}{l}\text { b. student's preparation } \\
\text { Total score } \\
\% \text { score } \\
\end{array}$ & $\begin{array}{c}28.21 \pm 6.65 \\
44.03 \pm 22.17 \\
\end{array}$ & 5 & \begin{tabular}{|c|}
$30.49 \pm 9.26$ \\
$51.65 \pm 30.87$ \\
\end{tabular} & 6 & $\begin{array}{l}t=1.83 \\
2\end{array}$ & 0.069 \\
\hline $\begin{array}{l}\text { unsafe clinical nurse } \\
\text { educator`s nractices } \\
\text { Total score } \\
\% \text { score }\end{array}$ & $\begin{array}{c}17.27 \pm 4.21 \\
45.95 \pm 23.37\end{array}$ & 4 & $\begin{array}{c}19.29 \pm 5.20 \\
57.19 \pm 28.87\end{array}$ & 5 & $\begin{array}{l}t=2.76 \\
2^{*}\end{array}$ & $0.006^{*}$ \\
\hline $\begin{array}{l}\text { unsafe nursing students - } \\
\text { CNE relationshin } \\
\text { Total score } \\
\% \text { score } \\
\end{array}$ & $\begin{array}{c}11.06 \pm 3.23 \\
42.18 \pm 26.95\end{array}$ & 7 & \begin{tabular}{|c|}
$12.87 \pm 3.92$ \\
$57.25 \pm 32.70$ \\
\end{tabular} & 4 & $\begin{array}{l}\mathrm{t}=3.24 \\
7^{*}\end{array}$ & $0.001^{*}$ \\
\hline $\begin{array}{l}\text { the educational program } \\
\text { Total score } \\
\% \text { score }\end{array}$ & $\begin{array}{c}14.60 \pm 3.53 \\
54.32 \pm 25.20\end{array}$ & 3 & $\begin{array}{c}16.32 \pm 4.09 \\
66.55 \pm 29.21\end{array}$ & 1 & $\mathrm{t}=2.88$ & $0.004^{*}$ \\
\hline $\begin{array}{l}\text { unsafe clinical learning } \\
\text { Total score } \\
\% \text { score } \\
\end{array}$ & $\begin{array}{r}24.16 \pm 5.16 \\
59.82 \pm 23.46 \\
\end{array}$ & 1 & $\begin{array}{c}24.32 \pm 6.51 \\
60.53 \pm 29.60 \\
\end{array}$ & 3 & $\begin{array}{l}\mathrm{t}=0.17 \\
3\end{array}$ & 0.863 \\
\hline $\begin{array}{l}\text { unsafe staff nurse`s practices } \\
\text { Total score } \\
\% \text { score }\end{array}$ & $\begin{array}{c}19.23 \pm 4.77 \\
56.86 \pm 26.50\end{array}$ & 2 & $\begin{array}{c}20.68 \pm 5.0 \\
64.90 \pm 27.77\end{array}$ & 2 & $\begin{array}{l}t=1.90 \\
7\end{array}$ & 0.058 \\
\hline
\end{tabular}

* Statistically significant at $\mathrm{p} \leq 0.05$.

\section{DISCUSSION:-}

One of the most critical experiences for student nurses is their exposure to patients in the clinical. It is where they encounter the human side of nursing. From an educational perspective, the clinical placement is the venue where skills, knowledge and attitudes 
developed in the theoretical part of the curriculum are applied, developed and integrated (Newton et al., 2010).

In total, the current study research findings showed that first and second academic year nursing students have significant different views regarding factor affecting safe clinical practices. There are significant differences between three of six factors. These factors are, unsafe clinical nurse educator`s practices, unsafe nursing students $-\mathrm{CNE}$ relationship and the educational program.

Thus regarding first year students the most effecting factors are unsafe clinical learning environment, On the other hand, regarding second year students the most effecting factor is the educational program, This finding is an indication for Students' inadequate preparation for entering the clinical environment creates problems for them also the ward learning environment has a lot of external stimuli which disadvantages the nursing students with respect to identifying the learning opportunities.

A finding similar to this current study revealed that High quality, practice-based education in a clinical setting is central to the preparation of future registered nurses; this is the environment in which students are able to apply their knowledge, learn key skills and achieve the required competence for entry to the register (Willis, 2015;Motiagh et al., 2012) reported that academic workload; unfamiliar situations in the clinical area, handling clinical emergencies and shortage of resources negatively impact on students' learning.

The result of study conducted by (Sharry et al., 2010) supported the study finding and indicated that Learning in a clinical setting creates challenges that are absent in a classroom setting. Facilitators have control of the environmental Conditions in the classroom whereas in the clinical setting, the teaching and learning are modified according to the situation of the real environment. The safety of Patients that the students are assigned to care for must be maintained. The clinical experiences of the nursing students' showed that they did experience challenges during their clinical rotations. The nursing students clearly expressed that the initial clinical experiences were stressful for them. Students in the level II experienced more anxiety compared to level III students.

(Tabari et al., 2006) reported it was mentioned in the studies that the quality of the clinical learning environment is one of the most influential factors on student learning. 
Moreover, Clinical teaching in is an important part of nursing education (Fakhr et al., 2012). Understanding the factors that influence the quality and quantity of clinical education is helpful in solving the related problems (Tavakoli, 2014). Nurses are repeatedly exposed to situations that may cause them to suffer and reduce their ability to serve the patients (Honkavuo and Lindström, 2012). Therefore, assessment of clinical skills by undergraduate nursing programmers is important to be considered (Rush et al., 2014). The importance of clinical nursing education is undeniable in personal, professional and clinical skills development (Taghinejad and Mehri, 2008). Through nursing education, nursing students will be able to obtain necessary knowledge and skills to assist public health (Abbaszade et al., 2013; Mabuda, 2008; Motiagh, 2012; Msiska, 2014) nursing students' received instructions totally different from what they are taught in the class room. The gap between theory and practice creates conflicts and influence the students learning negatively.

On the line with study finding This authors (Jahanmiri et al., 2004; Ebrahim, 2004; Zendehtalab, 1999; Hassan, 2008; Delaram et al., 2013 cited in Heidari and Norouzadeh, 2016) studies have proposed the clinical practices challenges from the students' perception, such as un availability of qualified instructors, lack of sufficient facilities, lack of cooperation of the staff in clinical education, lack of procedures to be practiced by students, lack of clinical education tasks, mismatch between objectives and the content of clinical education curriculum, lack of acquisition of prerequisites before entering the clinical fields, lack of appropriate opportunities for learning, lack of motivation among students, knowledge deficit about the profession, implementation of learned objectives in clinical setting, students' lack of awareness about the objectives and evaluation methods. Given the central role of students in clinical education, understanding their attitude toward the implementation of this method of education is necessary.

Lastly, the present study clarified that the most effecting factors on the student's clinical safety practices were unsafe staff nurse`s practices, the clinical educational program and unsafe clinical learning environment. In agreement with this findings, (Steivy et al., 2015) at College of Nursing, Benguet State University, La Trinidad, Benguet, Philippines. 


\section{CONCLUSION:}

Based on the results of the present study, the following can be concluded:

- The study findings concluded that regarding first year students the most effecting factor is unsafe clinical learning environment. In addition, second year students perceived the most effecting factor is the educational program. Also the unsafe clinical learning environment, second year students had higher level of perception about the effect of clinical learning environment on safe clinical practice.

- Personal-academic characteristics were having statistical significant relation upon factors affecting safe clinical practices as following:

- For first year students

- Student's gender was influencing factors upon their perception of student's rules commitment and Student's gender, previous educational qualification and months of previous clinical experiences were influencing factors upon their perception of the educational program.

- For second year students

- Student's financial resource was influencing factor upon their perception of unsafe nursing students - CNE relationship, student's age and financial resources were influencing factor upon their perception of the educational program and months of previous clinical experiences were influencing factors upon their perception of student preparation.

\section{RECOMMENDATIONS:}

Based on the findings of the current study, the following recommendations are suggested:

\section{Nurses should:}

- Appreciate working with students and their role and help them.

- Allow students independence one to participate in patient care.

- Orient the students to the ward routine and the people they are likely to encounter during their clinical training.

- Be a role model to the students in their practices and behaviors. 


\section{Hospital Manager should:}

- Emphases on the importance of patient safety issue.

- Organize training courses to enhance the nursing staff clinical practices.

\section{Ministry of Health should:}

- Find a solution to solve the nursing shortage problem.

- Make sure that essential equipment's and supplies are available.

\section{Technical Nursing Institute Management should:}

- Setting up suitable ratio of students to clinical nurse educators during clinical training.

- Developing the educational program to pay an equal attention to the clinical practices and the theoretical knowledge.

- Develop clinical skills, competences and behavior of CNE.

\section{Further Study:}

- Recommended in comparative with other Technical Nursing Institute to increase the power of generalizability of results and to examine other factors that affect clinical safety practices.

\section{REFERENCES:}

Abbaszade A, Borhani F, Sabzevari S. (2013): ursing teachers perception of the challenges of clinical education and solutions: A Qualitative Study. J Qual Res Health Sci. 2(2): 134-45. Persian.

Abdul-Aziz, H. Mohamed El-Habashy.(2014): Clinical safety practices as perceived technical institute nursing students. Alexandria University, Faculty of nursing, nursing administration department.

Chan DSK, Ip WY. (2007). Perception of hospital learning environment: A survey of Hong kong nursing students. Nurse Educ Today. 27:677-84. [PubMed].

Crotty J. (2010): Staff nurses and nursing students -learning from each other, Nursing 2010, March: 51-52 
Delaram M, Raeesi Z, Alidousti M. (2013). Strengths and weaknesses of clinical education from the perspectives of nursing and midwifery students of Shahrekord University of Medical Sciences. Qom University of Medical Sciences Journal. 6(2):1-6. Persian.

D’Souza MS, Karkada SN, Parahoo K, Venkatesaperumal R. (2015): Perception of and satisfaction with the clinical learning environment among nursing students. Nurse Educ Today.; 35:833-40.

Ebrahimi A. (2004). Assess and comparing the clinical problems of instructor and senior nursing students of Isfahan the school of nursing and midwifery [dissertation] Isfahan: Isfahan University of Medical Sciences; Persian.

Fakhr Movahedi A, Yousefpour M, Sadeghi S. (2013). Comparison of teaching behaviors of clinical nursing instructors from the perspective of nursing students of the public and private Universities of Semnan in 2012. Journal of medical education and development. 2013; 8(3): 81-95. Persian.

Fitzgerald M, Gibson F\& Gunn K. (2011): Contemporary issues relating to assessment of pre-registration nursing students in practice. Nurse Education in Practice, 10: $158-16$.

Gibson CG., (2011). Nurse educator roles and long-term care. Journal forNurses in Staff Development. 27: 259-261

Gillespie, M., \& McFetridge, B. (2009). Nurse education. The role of the nurse teacher. Journal of Clinical Nursing, 15, 639-644.

Hadizadeh F, Firoozi M, Shamaeyan Razavi N. (2005). Nursing and midwifery students' perspective on Clinical Education in Gonabad University of medical sciences. Iranian Journal of Medical Education. 5(1): 70-7. Persian.

Hassan Zahraei R, Atash Sokhan G, Salehi S, Ehsanpour $\quad$ S, Hassanzadeh, (2008).

A. Comparing the factors related to the effective clinical teaching from faculty members' and students' points of view. Iranian Journal of Medical Education. 7(2): 
249-56. Persian.

Heidari MR, Norouzadeh R. (2015): ursing students' perspectives on clinical education. J Adv Med Educ Prof.;3(1): 39-43. ursing students' perspectives on clinical education. Received: 9 June 2014. Accepted: 14 October 2014.

Honkavuo L, Lindström UA. (2012): urse leaders' responsibilities in supporting nurses experiencing difficult situations in clinical nursing. JNurs Manag. Nov 2; [Epub ahead of print].Contemporary Nurse 24 (2), 162-174.

Jahanmiri Sh, Ghodsbin F, Faseleh M, Zaighami R. (2004): Nursing

students' viewpoint about the problems of clinical teaching. The Journal of Qazvin University of Medical Sciences. 30(1):51-5. Persian.

Jecklin K. (2000) Evaluating the Student Clinical Learning Environment: Development and Validation of the SECEE Inventory EdD, MSN, RN Southern Online Journal of Nursing Research 4(1). Available at; www.snrs.org

Joolaee, S. R. Jafarian Amiri, Farahani M. A., and varaei S., (2015): "Iranian nursing students preparedness for clinical training: a qualitative study," urse Education Today, vol. 35, no. 10, pp. e13-e17. View at Publisher · View at Google Scholar · View at Scopus.

Kaphagawani NC, Useh U., (2013). Analysis of nursing students learning experiences in clinical practice: literature Review. Ethno Med; 7(3):181e5

Killam LA, Montgomery P, Luhanga FL, Adamic P, Carter LM., (2010): Views on unsafe nursing students in clinical learning. Int $J$ Nurs Educ Scholarsh, 7 (1):Article36.39(2): 67-73.

Killam LA, Luhanga F, Bakker D., (2011): Characteristics of unsafe undergraduate nursing students in clinical practice: an integrative literature review. J Nurs Educ, 50 (8):437 - 446).

Kirkpatrick LA, Feeney BC. (2013). A simple guide to IBM SPSS statistics for 
version 20.0. Student ed. Belmont, Calif.: Wadsworth, Cengage Learning.

Klab KA. (2008) Core competencies of nurse educators: Inspiring excellence in nurse educator practice. Nursing Education Perspectives. 29: 217.

Kotz S, Balakrishnan N, Read CB, Vidakovic B. (2006). Encyclopedia of statistical sciences. 2nd ed. Hoboken, N.J.: Wiley-Interscience.

LEofmark A, Thorkildsen K, Råholm MB, Natvig GK.,(2012) Nursing students' satis- faction with supervision from preceptors and teachers during clinical practice.Nurse Educ Pract;12:164e9.

Mabuda BT, Potgieter E, Alberts UU (2008): Student nurses' experiences during clinical practice in the Limpopo Province.

Moscaritolo LM, (2009). Interventional strategies to decrease nursing student anxiety in the clinical learning environment. J Nurs Educ.;48:17-23.

Motiagh GF, Karimi M, Hasanpour M (2012): Iranian nursing students' experiences of nursing. Iranian J Nursing Midwifery Res 17: S107-S114.

Msiska G, Smith P, Faecett T (2014): The "life world" of Malawian undergraduate student nurses: The challenges of learning in resource poor clinical settings. IJANS 1: 3542

Newton JM, Jolly BC, Ockerby CM \& Cross WM., (2010). A Clinical Learning Environment Scale: a factor analysis. Journal of Advanced Nursing 66, 1371-1481.

Rush S, Ooms A, Marks-Maran D, Firth T. (2014). Students' perceptions of practice assessment in the skills laboratory: An evaluation study of OSCAs with immediate feedback. Nurse Educ Pract. 2014 Jul 2; [Epub ahead of print] [PubMed]

Saarikoski M., Kaila P., Lambrinou E., Pérez Cañaveras RM., Tichelaar E., Tomietto M., Warne T.Students' (2013): experiences of cooperation with nurse teacher during their clinical placements: an empirical study in a Western European context. Nurse Educ Pract. 13:78-82. 
Scanlan JM, Care WD, Gessler S, (2001): Dealing with the unsafe student inclinical practice.Nurse Educ, 26(1):23-27.

Steivy U. Tiwaken, Lawrence C. Caranto, Juan Jose T. David, (2015): The Real World: Lived Experiences of Student Nurses during Clinical Practice. International Journal of Nursing Science 5(2): 66- 75.

Sharry Mc. E, McGloin H, Frizzell AM, O' Donnell LW (2010) : The role of the nurse lecturer in clinical practice in the Republic of Ireland. Nurse Educ Pract 10: 189195

Sundler AJ, Björk M, Bisholt B, Ohlsson U, Engström AK, Gustafsson M. (2014): Student nurses' experiences of the clinical learning environment in relation to the organization of supervision: a questionnaire survey. Nurse EducToday. 34:661 -6.

Tabari Khomeiran R, Yekta ZP, Kiger AM, Ahmadi F. (2006): Professional competence: Factors described by nurses as influencing their development. Int Nurs Rev.;53:66-72. (PubMed).

Taghinejad H, Mehri K. (2008). Barriers to Clinical Education. Journal of Kerman Nursing and Midwifery School. 14(1): 8. Persian.

Tavakoli M, Khazaei T, Tolyat M, Ghorbani S. (2014) The Quality of clinical education from the viewpoints of students and instructors of paramedical and nursing obstetrics schools of Birjand University of Medical Sciences. Daneshvar. 2014; 110:1-9. Persian.

Willis $P$ (2015). Quality with Compassion: The Future of Nursing Education. Report of the Willis Commission 2015, London: RCN. Available online at: http://www.williscommission.org.uk/_ data/assets/pdf_file/0004/489028/The_Willi s_Report_2012.pdf[Accessed December 20

Willis Commission, (2012). Quality with compassion: The future of nursing education: Report of the Willis Commission on Nursing Education. Retrieved from 
http://www.nursingtimes.net/Journals/2012/11/02/j/c/c/Willis-Commission-report2012.pdf.

World Alliance for Patient Safety (2011) Research for Patient Safety. Better Knowledge for Safer Care.2008. Retrieved on 25\6\2011.

Zendehtalab HR. (1999): Assess the quantity and quality of medical surgical lessons in nursing courses [dissertation]. Tehran: Tarbiat Modarres University. Persian.

\section{العوامل المؤثره على سلامه الممارسات العمليه كما ياركها طلاب المعهد القنى للتمريض ببورسعيد أ.د/ساميه محمد ادم1 ا.م.د// رضا ابراهيم الموافى2 نجلاء صلاح عابد33 \\ استاذ إدارة التمريض كلية التمريض جامعة عين شمس1. استاذ مساعد تمريض صحة الاسرة و المجتمع كلية التمريض جامعة بورسعيد²، اخصائيه تمريض بمستشفى عزبه البر ج بدمياط3}

\section{الـخلاصـة}

ان التمريض مجالا قائما على الممارسات العمليه. فان التدريب العملى اساسى للتعليم التمريضى، لذلك فان مهمة التعليم ماقبل العمل هى التاكد من ان الطلاب قادرين علىى تحقيق معايير السلامه و الجوده لرعايه المريض. ان الممارسات الغير امنه للطلاب هى السلوكيات التى تعرض المريض او فريق العمل للخطر النفسى او البدنى. هــف السبحث :تحديد العوامل المؤثره على سلامه الممارسات العمليه كما يدركها طلاب المعهد الفنى للتمريض ببورسعيد. التابع لوزاره

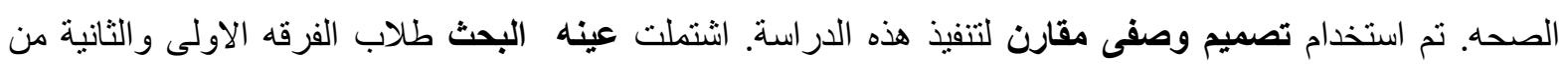
طلاب المعهد الفنى للتمريض تم تحديد عددهم طبقا للمعادله و هو (166 طالب) ، 81 طالب من الفرقه الاولى و 85 طالب من الفرقه الثانيه. نم استخدام استمارة استبيان لتحديد العوامل المؤثره على الممارسات العمليه الامنه كما يدركها طلاب التمريض بالمعهد الفنى ببورسعيد. النتـائسج: طبقا لمستوى التاثير 60٪ فان طلاب الفرقه الاولى لم يحققوه طبقا لاى من العوامل، اما طلاب الفرقه الثانيه فقد تمكنو امن تحقيقه طبقا لاثثين من العوامل و هم البرنامج التعليمى و الممارسات العمليه الغير آمنه لهيئه التمريض.هناك علاقه ذات دلاله احصائيه بين طلاب الفرقه الاولى و الثانيه طبقا ل الممارسات العمليه الغير امنه لمعلم التدريب العملى ، العلاقه بين الطالب و المعلم و البرنامج التعليمى. الخلاصه: بيئه

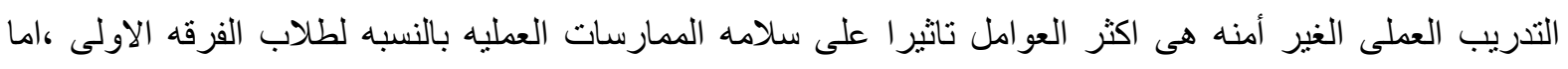
بالنسبه لطلاب الفرقه الثانيه فان البرنامج التعليمى هو أكثر العوامل تاثثير العلى سلامهـ الممارسات العمليه.التوصيات:العمل على تطوير البرنامج التعليمى بحيث يوفر التكافؤ بين المعرفه النظريه و الممارسات العمليه.

$$
\text { الكلمات المرشده : الممارسات العمليهطلاب التمريض، السلامه ، العو امل. }
$$

